\title{
Influence of deposition temperature on the properties of spray pyrolysed CdO thin films for TCO application
}

\author{
Fatma El-ashry ${ }^{1}$, Amira Zaki ${ }^{1}$, Mohamed El-hawary ${ }^{2}$, Mostafa Boshta ${ }^{3}$ \\ 1.Physics Department, Faculty of Women for Arts, Science and Education \\ Ain Shams University, Cairo, Egypt \\ 2.Physics Department, Faculty of Science, Menoufia University, Menoufia, Egypt \\ 3. Solid State Physics Department, National Research Centre, Cairo, Egypt
}

\begin{abstract}
Transparent and conducting cadmium oxide (CdO)thin films were deposited onto soda-lime glass substrate by simple chemical spray pyrolysis technique at different deposition temperatures. The influence of the deposition temperature on structural, morphological, electrical and optical properties of $\mathrm{CdO}$ films was investigated. X-ray diffraction patterns revealed that polycrystalline $\mathrm{CdO}$ phase with cubic crystal structure started to form at deposition temperature of $300{ }^{\circ} \mathrm{C}$ with secondary phase, while at lower deposition temperature the prepared layers showed amorphous structure. At deposition temperature higher than $300{ }^{\circ} \mathrm{C}$, the prepared layers showed single $\mathrm{CdO}$ phase enhanced crystallinity. Enhanced grain growth of $\mathrm{CdO}$ films is observed with increasing the deposition temperature. Moreover, the electrical conductivity of the films was found to be increasing with increasing the deposition temperature, which is consistent with the enhanced grain growth. Additionally, the optical transmittance measurement of the $\mathrm{CdO}$ films showed around $90 \%$ transmission in the visible and near infrared regions, independently of deposition temperature.
\end{abstract}

Keywords: Transparent conducting oxids; $\mathrm{CdO}$; spray pyrolysis; deposition temperature, and grain growth.

\section{Introduction}

Transparent conducting oxides (TCOs) are extensively used in optoelectronic devices such as flat panel display, organic light emitting diodes, photovoltaics, heat reflectors and energy efficient windows [ A.J. Freeman,.2000] - [D.S. Ginley.,2000] - [ H. Hosono.,2002] -

[H.L.Hartangel.,1995]-[ J.S. Kim.,1998]- [T. Minami.,1996]-[ T.J. Coutts.,2000]. Among many TCOs, cadmium oxide $(\mathrm{CdO})$ thin films have attracted considerable attention for various applications, due to its low electrical resistivity, high carrier concentration, nearly metallic conductivities and high optical transmittance in the visible region of the solar spectrum [ Saha B.,2007].CdO is an n-type semiconductor with a face centered cubic crystal structure and a direct band gap of approximately $2.5 \mathrm{eV}$ [ Carballeda-Galicia DM.,2000].CdO thin films have been prepared by various deposition techniques including reactive evaporation [ $\mathbf{Y}$.

Yang.,2005],[ A.A. Dakhel.,2003], solution growth,[G.Phatak.,1994]-[ R. Maity.,2006],sputtering, Carballeda-Galicia DM.,2000], [ A. Verkey.,1994], spray pyrolysis [ T.K. Subramanyam.,1997]-[ K. Gurumurugan1994], [ Hadaate Ullah.,2017] chemical bath deposition [ R.K.

Gupta.,2008],SILAR,MOCVD -[ A.W. Metz.,2004],[T. Minami1996] and PLD [ Saha B.,2007]-[ S. 
Jin.,2004]. Among these techniques, chemical spray pyrolysis technique is simple, cost effective and suitable for large area preparation.

In the present study, $\mathrm{CdO}$ thin films were deposited by chemical spray pyrolysis technique at different deposition temperatures between 200 and $450{ }^{\circ} \mathrm{C}$ using compressed air as carrier gas. The prepared films were characterized to study the influences of deposition temperature on their structural, morphological, electrical and optical properties.

\section{Experimental}

The CdO films were deposited onto soda-lime glass (SLG) substrates by spray pyrolysis technique. An aqueous solution of $0.1 \mathrm{M}$ cadmium acetate $\left(\left(\mathrm{CH}_{3} \mathrm{COO}\right)_{2} \mathrm{Cd} \cdot 2 \mathrm{H}_{2} \mathrm{O}\right)$ were dissolved in a distilled water. The desired chemical reaction is following:

$$
\begin{aligned}
& \mathrm{Cd}\left(\mathrm{CH}_{3} \mathrm{COO}\right)_{2} \cdot 2 \mathrm{H}_{2} \mathrm{O} \stackrel{\triangle}{\longrightarrow} \mathrm{Cd}\left(\mathrm{CH}_{3} \mathrm{COO}\right)_{2}+2 \mathrm{H}_{2} \mathrm{O} \\
& \mathrm{Cd}\left(\mathrm{CH}_{3} \mathrm{COO}\right)_{2}(\mathrm{~s}) \stackrel{\triangle}{\longrightarrow} \mathrm{CdO}(\mathrm{s})+\mathrm{CH}_{3} \mathrm{COCH}_{3}(\mathrm{~g})+\mathrm{CO}_{2}(\mathrm{~g})
\end{aligned}
$$

The deposition parameters such as spray nozzle-substrate distance $(25 \mathrm{~cm}$, solution rate $(0.66$ $(\mathrm{ml} / \mathrm{min}))$ and pressure of carrier gas $(25(\mathrm{~L} / \mathrm{min}))$ were optimized. The solution was sprayed onto preheated SLG at deposition temperatures of 200, 300, 350, 400 and $450{ }^{\circ} \mathrm{C}$.X-ray diffraction (XRD) patterns of prepared films were obtained by Philips diffractometer model (PW3040) using $\mathrm{K}_{\alpha 1}$ radiation $(\lambda=1.54 \AA$ ). The morphology of the films was studied by Scan Electronic Microscope FEI Quantum model (FEG 250). The thickness of the prepare films were measured using a Stylus profilmeter model (Dektak 150). The optical transmittance (T) and reflectance (R) were obtained by UV/Vis/NIR spectrophotometer model (Jasco-670) in the wavelength range $200-2500 \mathrm{~nm}$.

\section{Results and discussion}

\subsection{Structural properties}

Fig.1(a,b,c\&d) shows X-ray diffraction patterns for the samples deposited at deposition temperatures of $300,350,400,450^{\circ} \mathrm{C}$ respectively. X-Ray diffraction patterns of the deposited films showed that $\mathrm{CdO}$ phase begin to form at $300^{\circ} \mathrm{C}$, where the deposited films at $200^{\circ} \mathrm{C}$ were amorphous. The deposited films at $200^{\circ} \mathrm{C}$ were amorphous as the temperature is not enough to form $\mathrm{CdO}$ phase, while at $300{ }^{\circ} \mathrm{C}$ the peaks of $\mathrm{CdO}$ begin to appear with an unidentified phase where the temperature is not sufficient for the complete evaporation and decomposition of the starting precursors. However, by further increase in the deposition temperature, the secondary phase disappeared and $\mathrm{CdO}$ reflections became stronger and sharper as the crystallinity started to enhance with further increase in the deposition temperature. The observed $\mathrm{CdO}$ reflections were indexed according to the cubic structure (JCPDS no. 05-0640) showing reflections corresponding to(111),(200), (220),(311) and (222) planes. 


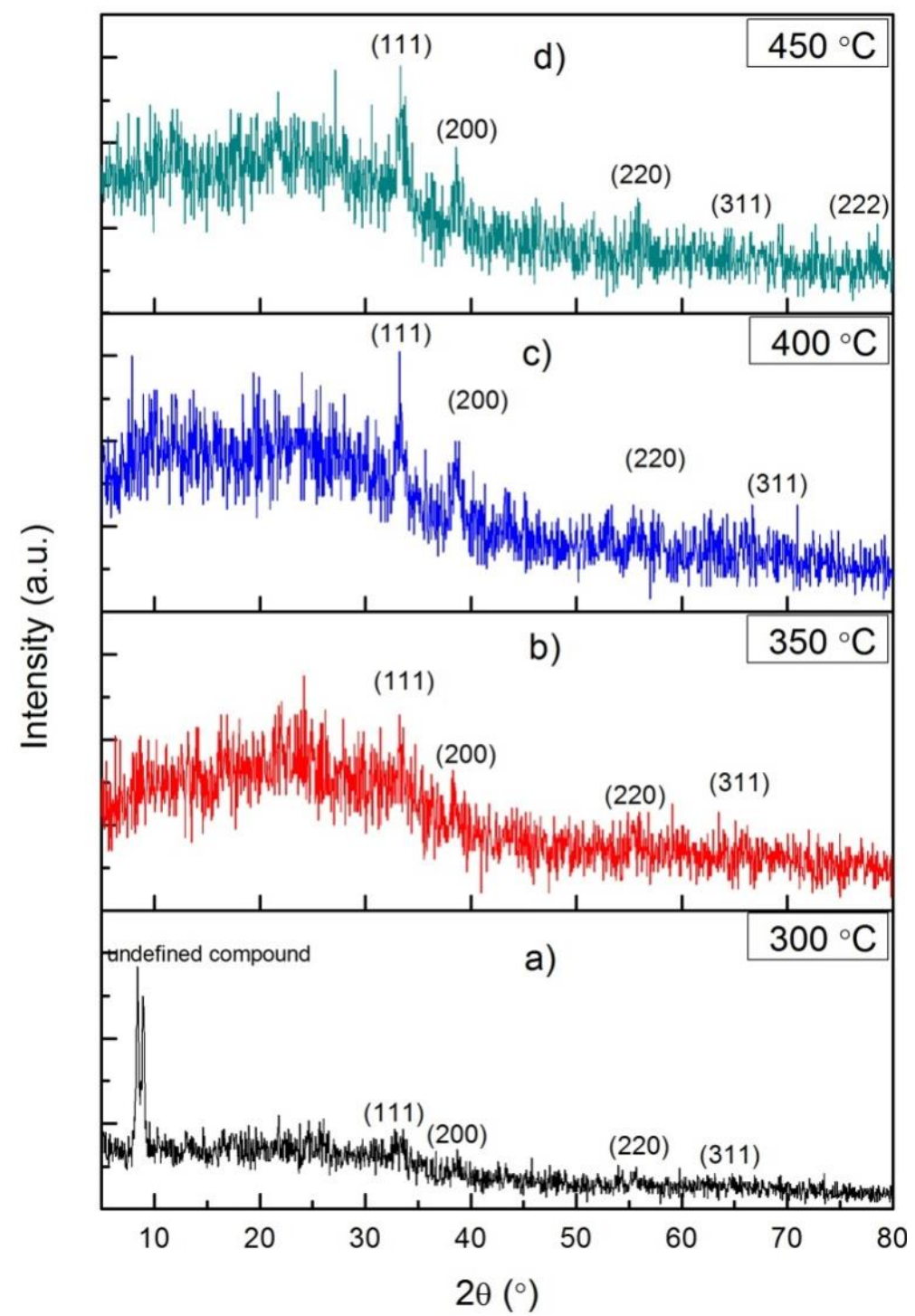

Fig. 1. X-ray diffraction patterns of $\mathrm{CdO}$ thin films at temperatures $300,350,400$ and $450{ }^{\circ} \mathrm{C}$ :

The average crystal grain size (D) was estimated using

Scherrer's formula [ B.D. Cullity.,1956]:

$$
D=\frac{0.94 \lambda}{\beta \cos \theta}(3)
$$

where $\theta$ is the usual Bragg angle and $\beta$ is the full width at half-maxima of the diffraction peaks.

The structural parameters for $\left(\begin{array}{lll}1 & 1 & 1\end{array}\right)$ crystallographic orientation of the $\mathrm{CdO}$ thin films shows that with increasing the deposition temperature from $300{ }^{\circ} \mathrm{C}$ to $450{ }^{\circ} \mathrm{C}$, the crystallite size increases from $10.8 \mathrm{~nm}$ to $24 \mathrm{~nm}$, indicating improvement in the crystallinity of the films with increasing the deposition temperature.

\subsection{Morphological properties}


SEM is a convenient technique to study the surface morphology of thin films. Fig. 2a,b,c and $\mathrm{d}$ show the SEM images of the $\mathrm{CdO}$ thin films deposited at deposition temperatures of 300 , 350,400 and $450{ }^{\circ} \mathrm{C}$ respectively. The surface property of the $\mathrm{CdO}$ films appears to change as a function of deposition temperature. The grain growth of $\mathrm{CdO}$ was found to be enhanced with increasing deposition temperature as shown in Fig. 2. With increasing the deposition temperature, the small clusters are merged with each other to form bigger grains and the $\mathrm{CdO}$ films become more compact, dense and adhered to the entire substrate without any cracks.
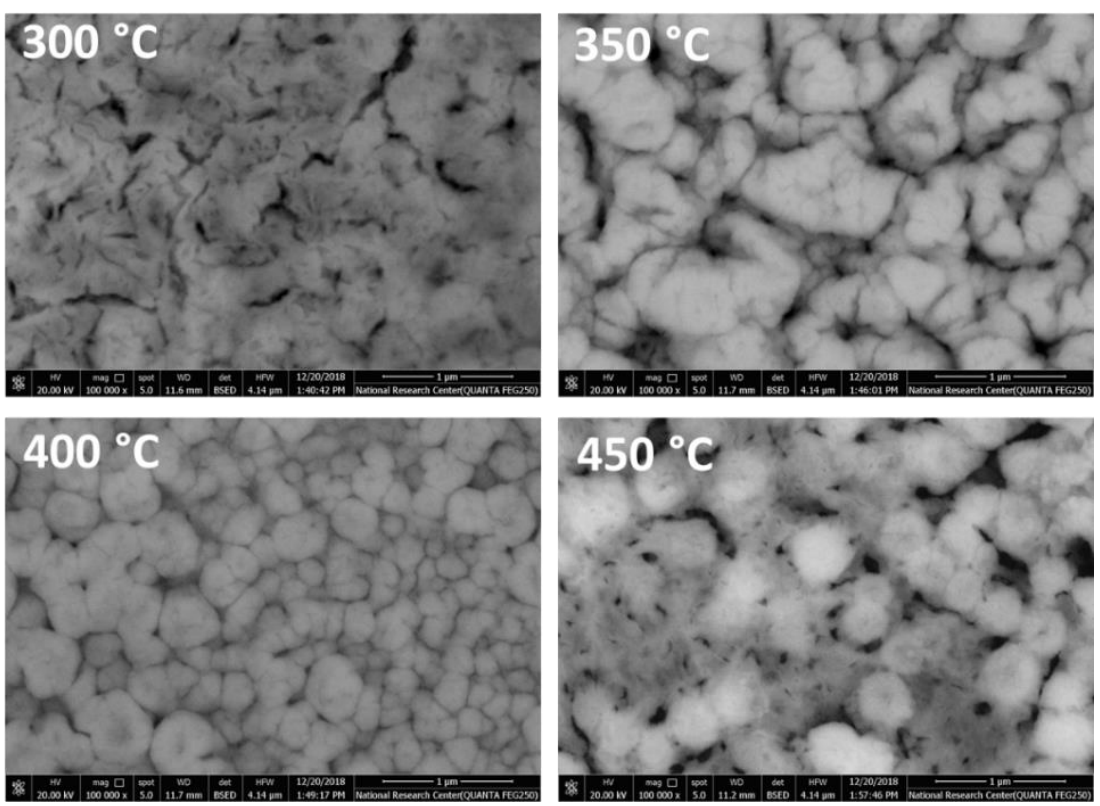

Fig. 2. SEM images of CdO thin films sprayed at 300,350,400 and $450^{\circ} \mathrm{C}$

\subsection{Electrical properties}

The electrical conductivity of $\mathrm{CdO}$ thin films prepared at different deposition temperature was measured using two-probes configuration. Fig. 3 shows the variation of electrical conductivity with deposition temperature. The electrical conductivity increased with increasing deposition temperature, which may be attributed to the enhanced crystallinity and grain growth of the films with increasing the deposition temperature.

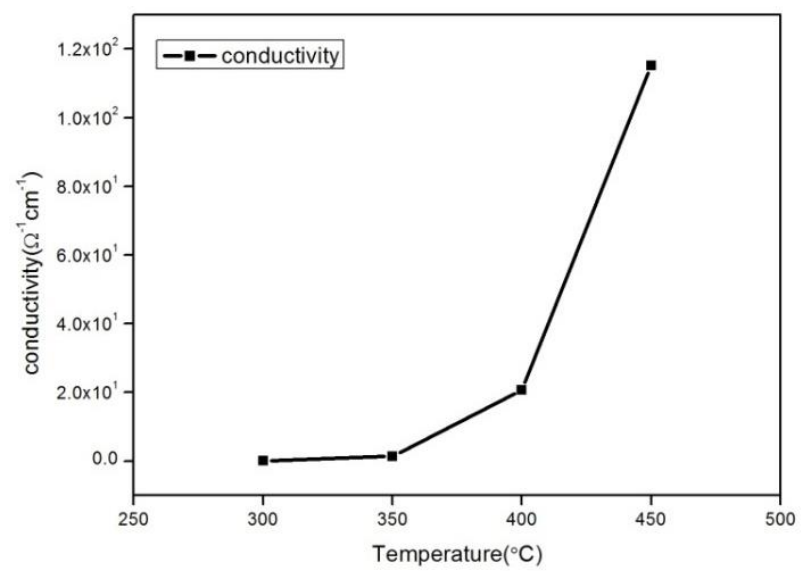

Fig. 3) conductivity of $\mathrm{CdO}$ thin film deposited at different depositiontemperatures for $15 \mathrm{~min}$. 


\subsection{Optical properties}

The optical transmittance spectra for the CdOthin films prepared at different temperatures are shown in Fig. 4. All prepared films show high transperancy in both visible and near IR regions. It can be seen that by increasingthe deposition temperature, the transperancy increase. This inhancing in the transperancy can be attrebuted to decrease in thin film thickness, where the thicknessof the film prepared at $300,350,400,450{ }^{\circ} \mathrm{C}$ are $410,310,167$ and $162 \mathrm{~nm}$ respectivlly. At $450^{\circ} \mathrm{C}$ theprepared $\mathrm{CdO}$ thin film shows higher transimission which reach to up $90 \%$.

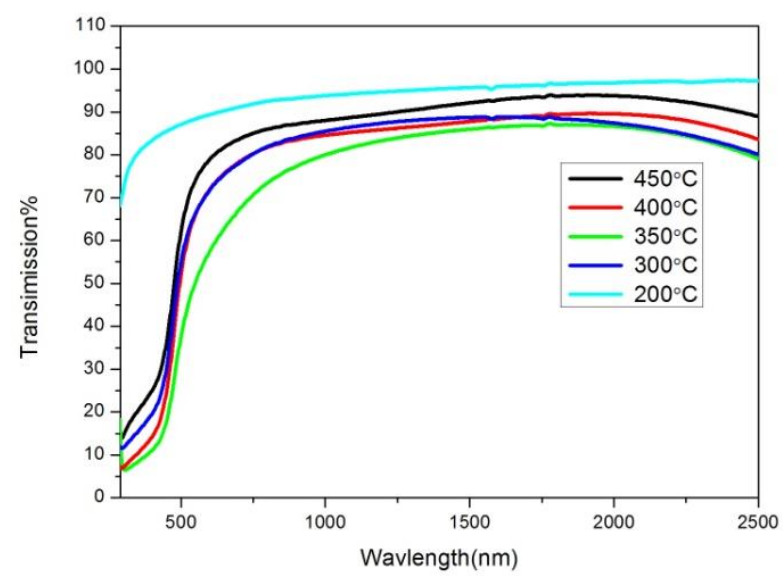

Fig. 4. Influence of different $\mathrm{T}_{\text {sub }}$ on the optical transmission spectrum of $\mathrm{CdO}$

The Eg value can be calculated usingthe fundament absorption, which corresponds to electron excitationfrom the valance band to conduction band. Eg is usually obtained byextrapolations of the linear portion of the plots of $(\alpha h v)^{2} v s$. hv, as shown in Fig. 5, where hv is photon energy and $\alpha$ is theabsorption coefficient expressed as:

$$
\alpha=\frac{\ln \left(\frac{1}{\mathrm{~T}}\right)}{d}
$$

where $\mathrm{T}$ is transmittance and $\mathrm{d}$ is film thickness.

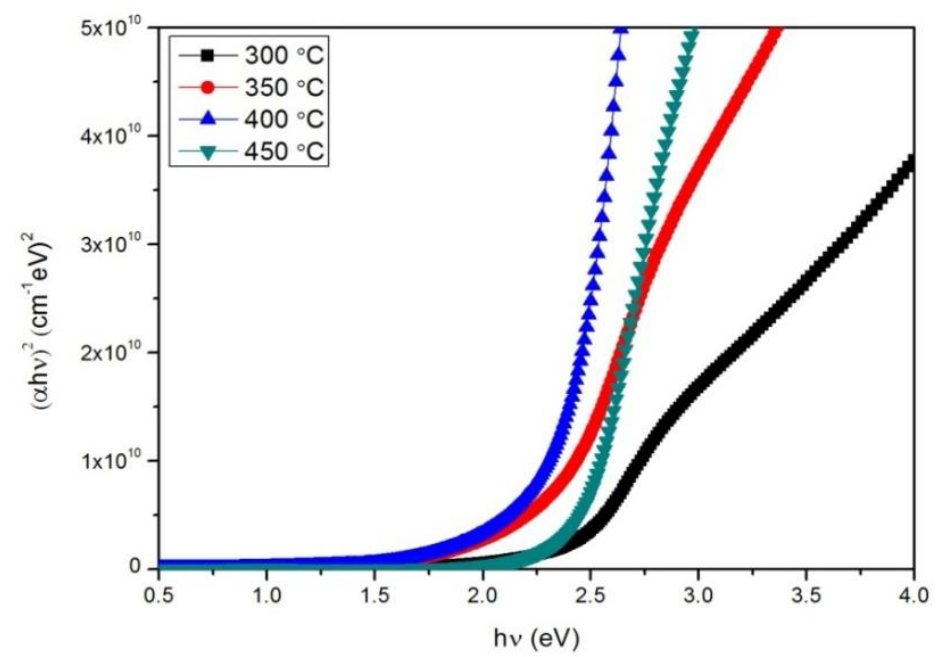

Fig(5) Relation between $(\alpha h v)^{2}$ and hv for CdO thin films prepared at different temperature 
The relation between theabsorption coefficient and the incident photon energy (hv)isgiven by the equation(6)

$$
(\alpha h v)^{2}=A\left(h v-E_{g}\right)
$$

where ' $\mathrm{A}$ ' is a constant and ' $\mathrm{Eg}$ ' is optical band gap.

The value of direct energy band gap Eg is about $2.3 \mathrm{eV}$ whichis in agreement with the literature[.A.J.Varkey1993]\&(I.BenMiled2017).

From Fig(5) it can be seen that there are two energy bands for films prepared at 300 and 350 ${ }^{\circ} \mathrm{C}$ confirming that there are two phases in the prepared films. For films prepared at 400 and $450^{\circ} \mathrm{C}$ there is just one energy band gap indicating one phase in $\mathrm{CdO}$ films.

\section{Conclusion}

Highly conducting and transparent $\mathrm{CdO}$ thin films were successfully deposited on soda lime glass substrate by spray pyrolysis technique. The influence of the deposition temperature on structural, morphological, electrical and optical properties of $\mathrm{CdO}$ films was investigated. Xray diffraction patterns revealed that polycrystalline $\mathrm{CdO}$ phase with cubic crystal structure begin to form at deposition temperature of $300{ }^{\circ} \mathrm{C}$. The film grown at deposition temperature $450{ }^{\circ} \mathrm{C}$ ) show high crystallinity, high transmittance up to $90 \%$ in the visible and near infrared regions, low resistivity $\left(86.8 \times 10^{-4} \Omega \mathrm{cm}\right)$. These highly conducting and transparent $\mathrm{CdO}$ thin films could be an excellent candidate for future optoelectronic applications.

\section{Acknowledgements}

We gratefully acknowledge and thank to Dr M.H. Sayed and Dr M. Gomaa for their inducement and valuable help. I would like also to thank my mother and Dr.Ibrahem serour for their support.

\section{References}

1. A.A. Dakhel, F.Z. Henari, Cryst. Res. Technol. 38 (2003) 979.

2. A.J. Freeman, K.R. Poeppelmeier, T.O. Mason, R.P.H. Chang, T.J. Marks, MRS Bull. 25 (2000) 45

3. A. J. Varkey, A, F. Fort, Transparent conducting CdO prepared by solution growth, Thin Solid Films, 239 (1994) 211-213

4. A. Verkey, A.F. Fort, Thin Solid Films 239 (1994) 211.

5. A.W. Metz, J.R. Ireland, J.G. Zheng, R.P.S.M. Lobo, Y. Yangm, J. Li, C.L. Stern,V.P. Dravid, N. Bontemps, C.R. Kannewurf, K.R. Poeppelmeier, T.J. Marks, J.Am. Chem. Soc. 126 (2004) 8477.

6. B.D. Cullity, Elements of X-Ray Diffraction, Addison-Wesley Publications Company Inc., Reading, Massachusetts, 1956.

7. Carballeda-Galicia DM, Castanedo-Pérez R, Jiménez-Sandoval O, Jiménez-SandovalS, TorresDelgado G, Zúñiga-Romero CI. Thin Solid Films 2000;371:105.

8. D.S. Ginley, C. Bright, MRS Bull. 25 (2000) 15.

9. G. Phatak, R. Lal, Thin Solid Films 245 (1994) 17.

10. I. Ben Miled,Structural, optical, and electrical properties of cadmium oxide thinfilms prepared by solgel spin-coating method,J Sol-Gel SciTechnol (2017) 83:259-267

11. H. Hosono, H. Ohta, M. Orita, K. Ueda, M. Hirano, Vacuum 66 (2002) 419.

12. H.L. Hartangel, A.L. Dawar, A.K. Jain, C. Jagadish, in: Semiconducting Transparent Thin Films, Institute of Physics, London, 1995.

13. Hadaate Ullah, Ridoanur Rahaman, Shahin Mahmud ,Indonesian Journal of Electrical Engineering and Computer Science, 5(1) (2017) 81-84. 
14. J.S. Kim, M. Granstr “ om, R.H. Friend, N. Johansson, W.R. Salaneck, R. Daik, W.J. Feast, J. Appl. Phys. 84 (1998) 6859.

15. K. Gurumurugan, D. Mangalraj, S.K. Narayandass, Thin Solid Films 251 (1994)7.

16. L.R. Gutierrez, J.J.C. Romero, J.M.P. Tapia, E.B. Calva, J.C.M. Flores, M.O. Lopez,Mater. Lett. 60 (2006) 3866.

17. R. Maity, K.K. Chattopadhyay, Sol. Energy Mater. Sol. Cells 90 (2006) 597.

18. R.K. Gupta, K. Ghosh, R. Patel, S.R. Mishra, P.K. Kahol, Mater. Lett. 62 (2008)3373.

19. R.K. Gupta, K. Ghosh, R. Patel, S.R. Mishra, P.K. Kahol, Curr. Appl. Phys. 9(2009) 673.

20. Saha B, Das S, Chattopadhyay KK. Sol Energy Mater Sol Cells 2007;91:1692.

21. S. Jin, Y. Yang, J.E. Medvedeva, J.R. Ireland, A.W. Metz, J. Ni, C.R. Kannewurf,A.J. Freeman, T.J. Marks, J. Am. Chem. Soc. 126 (2004) 13787.

22. T.K. Subramanyam, B.R. Krishna, S. Uthanna, B.S. Naidu, P.J. Reddy, Vacuum48 (1997) 565.

23. T. Minami, T. Kakumu, S. Tanaka, J. Vac. Sci. Technol. A 14 (1996) 1704.

24. T.J. Coutts, D.L. Young, X. Li, W.P. Mulligan, X. Wu, J. Vac. Sci. Technol. A 18 (2000) 2646.

25. Y. Yang, S. Jin, J.E. Medvedeva, J.R. Ireland, A.W. Metz, J. Ni, M.C. Hersam,A.J. Freeman, T.J. Marks, J. Am. Chem. Soc. 127 (2005) 8796.

\title{
الملخص باللغة العربية
}

\section{تأثير درجه حرارة الترسيب علي خصائص الأغشية الرقيقة من أكسيد الكادميوم المحضرة بطريقه

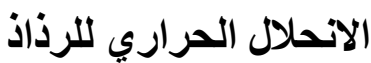

\author{
فاطمة العشري' اميره زكي' محمد الهواري' مصطفي بوشتهـ' \\ ا ـقسم الفيزياء كليه البنات للاداب و العلوم و التربيه جامعه عين شمس هليوبلس القاهره \\ r- قسم الفيزياء كليه العلوم جامعه المنوفيه شبين الكوم المنوفيه \\ ب-قسم فيزياء الجوامد المركز القومي للبحوث الرقم البريدي الاسب الدقي الجيزه
}

نم تحضير اغشية رقيقة من اكسيد الكادميوم بطريقة الانحلال الحراري بالرذاذ ودراسة تأثثر درجات حرارة الترسيب المختلفة علي الخو اص الفيزيائية للعينات المحضرة واظهرت النتائج ان الكسيد الكادميوم بدأ في التكون عند درجه حراره . . ب درجه سيليزيه وان نسبه التبلور للعينات تزداد مع زياده درجه الحر اره وكذللك وجد ان الخواص الضوئيه والكهربيه

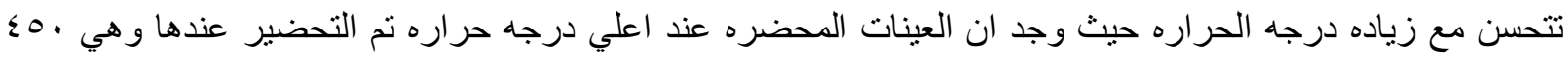
درجه سيليزيه تتمتع باعلي نسبه تبلور واعلي توصيليه كهربيه وكنللك اعلي شفافيه للضوء سو اءه في النطاق الضونئي او نطاق الاشعه تحت الحمر اء. 